\title{
Management of Grassland-like Wildflower Strips Sown on Nutrient- rich Arable Soils: The Role of Grass Density and Mowing Regime
}

\author{
Julien Piqueray ${ }^{1}{ }^{1} \cdot V^{2}$ alentin Gilliaux ${ }^{1} \cdot$ Virginie Decruyenaere $^{2} \cdot$ Jean-Thomas Cornelis $^{3} \cdot$ Roel Uyttenbroeck $^{4,5} \cdot$ \\ Grégory Mahy 4
}

Received: 18 October 2018 / Accepted: 26 February 2019 / Published online: 13 March 2019

(c) Springer Science+Business Media, LLC, part of Springer Nature 2019

\begin{abstract}
Wildflower strips (WS) are proposed in many European countries as a strategy to enhance biodiversity and ecosystem services in arable fields. To create and maintain WS on nutrient-rich cultivated soils reveals challenging. Flowered species may be outcompeted by grasses due to high phosphorus content in soil. We studied during 5 years seed mixture (grass density in the seed mix) and mowing regime influenced the ability of WS to provide environmental benefits (flower provision for insects and landscape purposes, reduction of soil nutrient load) and respond to farmer concerns (noxious weed promotion, forage production). Lowered grass density increased flower abundance, but not diversity, only in the first 3 years. In the last 2 years mowing effects became determinant. Flower cover and richness were the highest under the twice-a-year mowing regime. This regime also increased forage quantity and quality. Flower colour diversity was conversely the highest where mowing occurred every two years. Potassium in the soil decreased under the twice-a-year mowing regime. Other nutrients were not affected. No management option kept noxious weed to an acceptable level after 5 years. This supports the need to test the efficacy of specific management practices such as selective clipping or spraying. Mowing WS twice a year was retained as the most favourable treatment to maintain species-rich strips with an abundant flower provision. It however implies to mow in late June, i.e. at the peak of insect abundance. It is therefore suggested to keep an unmown refuge zone when applying this management regime.
\end{abstract}

Keywords Agri-environment Schemes $\cdot$ Plant diversity $\cdot$ Soil nutrients $\cdot$ Weed management $\cdot$ Wildflower strips

Supplementary Information The online version of this article (https://doi.org/10.1007/s00267-019-01153-y) contains supplementary material, which is available to authorised users.

Julien Piqueray

jpiqueray@natagriwal.be

1 Natagriwal ASBL, site de Gembloux, Passage des Déportés 2, Gembloux 5030, Belgium

2 Walloon Agricultural Research Centre (CRA-W) - Production and Sectors Department, Rue de Liroux 8, Gembloux 5030, Belgium

3 Gembloux Agro-Bio Tech, Department BIOSystem Engineering (BIOSE),Water - Soil - Plant Exchanges, University of Liege, Passage des Déportés 2, Gembloux 5030, Belgium

4 Gembloux Agro-Bio Tech, Biodiversity and landscape Unit, University of Liege, Passage des Déportés 2, Gembloux 5030, Belgium

5 Gembloux Agro-Bio Tech, TERRA - AgricultureIsLife, University of Liege, Passage des Déportés 2, Gembloux 5030, Belgium

\section{Introduction}

In the face of environmental degradation due to agriculture intensification, many European countries adopted Agrienvironment Schemes (AES) as a response (Batáry et al. 2015). Among those schemes, flower strips are often proposed as a strategy to enhance flower-feeding insect biodiversity (Haaland et al. 2011) as well as ecosystem services, such as pollination (Nicholls and Altieri 2013; Uyttenbroeck et al. 2017), natural pest control (Landis et al. 2000; Hatt et al. 2017, 2018) and improvement in landscape aesthetics (Junge et al. 2015). The type of strips and their management may vary between countries, depending on their policy (Haaland et al. 2011). Several countries adopted AES prescription for perennial field margins made of indigenous forbs and grasses managed by mowing, with the aim to keep meadow-like vegetation (Smith et al. 2010; Haaland et al. 2011; Tarmi et al. 2011). In this way, Walloon (South Belgium) AES management prescriptions for wildflower strips include the use of species typical from 
local lowland hay meadows (Piqueray et al. 2016) and mowing as a management. They therefore aimed at creating habitats analogous to these ecosystems, known to be particularly attracting to insects, but in strong decline in Europe (Ridding et al. 2015; Staab et al. 2015). Doing this, they may contribute to the preservation of species related to this ecosystem, alongside historical site preservation and restoration (Kiehl and Pfadenhauer 2007; Staab et al. 2015). Such strips are likely to provide a further advantage for farmers in the form of forage production (De Cauwer et al. 2006a). However, farmers can be at a loss as to how using forage from their strips (Bruinenberg et al. 2002; De Cauwer et al. 2006a). Some other concerns may rose from farmers adopting wildflower strip AES. One major concern is about the risk to promote noxious weeds (Smith et al. 2010). Despite several implications in terms of farmer acceptance of AES, these multiple aspects have rarely been studied (Uyttenbroeck et al. 2016), but see works by De Cauwer et al. (2006a, b, 2008). It is therefore imperative to know how to implement and manage flower strips in order to make them both effective regarding their aims and acceptable to farmers.

To create and maintain wildflower strips analogous to hay meadows on nutrient-rich cultivated soils reveals somewhat challenging. Indeed, especially the high phosphorus content is known to be unsuitable to the development of species-rich grasslands (Janssens et al. 1998). In such fertile conditions, grasses tend to become dominant at the expense of flowering species (Schellberg et al. 1999; Mountford et al. 2016). Especially, the growth of legumes may be restricted due to their low competitive abilities against grasses in nutrient-rich ecosystems (Zanetti et al. 1996). This in turns affects forage quality, as fewer legumes in the forage can lead to lower protein content. The inclusion of grasses in wildflower strips seed mixture is therefore a questionable management practice (Staab et al. 2015). On the one hand, it may affect the emergence of the sown flowers which would affect both insect attraction and landscape aesthetics improvement. But on the other hand, grass species may be useful at the implementation of field margins, as they can help controlling weed emergence through clonal field occupation (Hansson and Fogelfors 1998). The question arises therefore which proportion of grass to sow in order to promote flowers while maintaining weeds at an acceptable level.

Furthermore, the mowing regime has been shown to be a main driver of plant community composition in grassland ecosystems (Kahmen et al. 2002). Mowing can indeed decrease the inter- and intraspecific competition, therefore permitting the co-existence of numerous species in a small scale (Tälle et al. 2016). In many countries, wildflowers strips are left unmanaged (Scheper et al. 2015). In others, annual late-summer or winter mowing may be prescribed
(Haaland et al. 2011; Tarmi et al. 2011). However, a recent study pointed out that early-summer mowing was more efficient to maintain forbs in nutrient-rich contexts (Kirmer et al. 2018). It also offers the advantage that flowers may regrow in the late-summer and that a second forage harvest may be available to farmers in autumn. This results in a twice-a-year mowing frequency, identified by Uchida and Ushimaru (2014) as an intermediate disturbance regime (between land abandonment and intensification) particularly favourable to maintain plant and insect species richness in agricultural lands. Also, in the absence of soil fertilisation, increased biomass uptake through multiple cuttings is likely to diminish soil nutrient stocks (Oelmann et al. 2007), therefore conducting to soil condition more suitable for the maintenance of meadow species (Critchley et al. 2002). Moreover, adapting mowing date may help to prevent weed infestation (Smith et al. 2010). Forage yield and quality are also likely to be decreased in cases of delayed mowing (Bruinenberg et al. 2002). There is therefore a need to test how mowing regime is able to modulate benefits generated by wildflower strips.

In this study, we aimed to explore, through an experimental design, how management options in grassland-like wildflower strips may influence their ability to provide environmental benefits (flower provision for insects and landscape purposes, reduction of soil nutrient load) and respond to main farmer concerns (noxious weed promotion, forage quantity and quality). We first hypothesize that decreasing grass density should result in increasing flower provision, but should also promote weed development. Second, increasing mowing frequency should increase flower provision, forage quantity and quality and help controlling weeds. It should result in soil nutrient depletion due to increasing forage exportation. Through the verification of these hypotheses, we aimed at determining which option may optimise ecological benefits and farmer acceptance for AES.

\section{Materials and Methods}

\section{Study Site and Experimental Design}

The experiment was implemented in April 2010. It was located in Gembloux (Belgium, Wallonia; 50 33'45' $\mathrm{N}$; 442'22' E; alt. $170 \mathrm{~m}$; annual mean temperature ca. $9^{\circ} \mathrm{C}$, annual rainfall ca. $800 \mathrm{~mm}$ ). Soil at the site is very fertile (WRB soil group: retisol). It was previously occupied by an intensive arable field devoted to growing cereals and row crops (previous 3-year rotation: potatoes, spelt and winter barley). Two seeds mixtures, differing in amount of grass seed present, were tested (Table 1): (1) the seed mixture with high grass density $\left(G_{\text {high }}\right)$ was composed of $85 \%$ 
Table 1 List of species and sowing densities in the $G_{\text {high }}$ and $G_{\text {low }}$ modalities

\begin{tabular}{|c|c|c|c|c|}
\hline Species & Type & $\begin{array}{l}G_{\text {high }} \\
(\mathrm{kg} / \mathrm{ha})\end{array}$ & $\begin{array}{l}G_{\text {low }} \\
(\mathrm{kg} / \mathrm{ha})\end{array}$ & Colour \\
\hline Agrostis capillaris L. & Grass & 3 & 1.5 & I \\
\hline Festuca rubra $\mathrm{L}$. & Grass & 15 & 7.5 & I \\
\hline Poa pratensis $\mathrm{L}$. & Grass & 7.5 & 3.75 & l \\
\hline Achillea millefolium $\mathrm{L}$. & Forb & 0.15 & 0.15 & White \\
\hline Centaurea cyanus L. & Forb & 0.3 & 0.3 & Blue \\
\hline Centaurea jacea $\mathrm{L}$. & Forb & 0.45 & 0.45 & Purple \\
\hline Daucus carota $\mathrm{L}$. & Forb & 0.45 & 0.45 & White \\
\hline Glebionis segetum (L.) Fourr. & Forb & 0.3 & 0.3 & Yellow \\
\hline Leucanthemum vulgare Lam. & Forb & 0.9 & 0.9 & White \\
\hline Malva moschata $\mathrm{L}$. & Forb & 0.45 & 0.45 & Pink \\
\hline Papaver rhoeas $\mathrm{L}$. & Forb & 0.3 & 0.3 & Red \\
\hline $\begin{array}{l}\text { Silene latifolia subsp. alba } \\
\text { (Mill.) Greuter \& Burdet }\end{array}$ & Forb & 0.75 & 0.75 & White \\
\hline Lotus corniculatus L. & Legume & 0.1725 & 0.1725 & Yellow \\
\hline Medicago lupulina $\mathrm{L}$. & Legume & 0.15 & 0.15 & Yellow \\
\hline Trifolium pratense $\mathrm{L}$. & Legume & 0.1275 & 0.1275 & Purple \\
\hline Total & & 30 & 17.25 & \\
\hline
\end{tabular}

Colour is the flower colour considered to compute colour diversity

grasses and $15 \%$ flowers. This proportion, as well as the applied sowing density $(30 \mathrm{~kg} / \mathrm{ha})$ correspond to the recommendation of the seed provider; (2) the seed mixture with lower grass density $\left(G_{\text {low }}\right)$ had the same flower seed density and composition as $G_{\text {high }}$ but the grasses seed density was divided by two. The $G_{\text {low }}$ was therefore sown at $17.25 \mathrm{~kg} / \mathrm{ha}$ (Table 1). The three mowing regimes applied were: (1) once a year in August-September (MOW1); (2) once every two years in August-September (MOW0.5); (3) twice a year in late June and in August-September (MOW2). MOW1 corresponds to the prescription that was applied in the Walloon wildflower strips AES at the beginning of the experiment. MOW0.5 and MOW2 were introduced as alternative management options. Mowing regime application began in 2011. In 2010 (first year), all plots were mown only in September. Mowing was accomplished by a plot harvester (Haldrup $($ ) with Busatis (C) cutting blade) and forage was removed. The experiment was therefore made of six treatments ( 2 sown grass densities*3 mowing regimes). It contained four replicates, corresponding to four blocks, and was therefore composed of 24 experimental plots. Plot size was $60 \mathrm{~m}^{2}$ $(6 \times 10 \mathrm{~m})$. Within each block, plots were placed according to a strip-plot design, with seed mix placed longitudinally and mowing regimes transversely within each block (Fig. 1).

\section{Floristic Survey}

In each of the 24 plots, six permanent $1 \mathrm{~m}^{2}$-quadrats were placed for vegetation surveys. In these quadrats, the horizontal cover of all the sown species was recorded each year from 2010 to 2014 in early June, at the peak of vegetation. Unsown weed species were not recorded individually, but instead as a global problematic weed species cover (annual arable weeds, Cirsium arvense and Rumex crispus/obtusifolius). As indicators for flower-feeding insects and landscape interests, we computed the following metrics:

Flowering plant species richness (insects)

Total flowering plant cover (insects and landscape)

Flowering plant Shannon's diversity (insects)

Flower colour Shannon's diversity (landscape)

Flower colour diversity indeed proved to be an important feature in landscape aesthetics (Stilma et al. 2009; Junge et al. 2015). Flower colour was assessed based on field observation and is provided in Table 1. To compute the colour diversity, horizontal cover of the species with identical colour was summed to obtain a total cover for each colour. Species richness and Shannon's diversity were calculated, as they have been shown to be relevant for flowerfeeding insects in previous studies (Ebeling et al. 2008; Fründ et al. 2010).

\section{Forage Yield and Forage Analyses}

The plot harvester directly provided fresh matter yields (FMY) for each mown plot, each year between 2010 and 2014, in three distinct $1.5 \times 6 \mathrm{~m}$ strips within the plot. In each plot, one ca. $1 \mathrm{~kg}$ fresh forage sample was taken at the moment of mowing. It was weighed and then dried in an oven $\left(65^{\circ} \mathrm{C}\right.$ for $\left.36 \mathrm{~h}\right)$ in order to measure dry matter content (DMC) and subsequently calculate dry matter yield (DMY).

In 2014, dried samples were ground in a hammer mill (1 mm screen; Waterleau, BOA, Belgium) and then ground again in a Cyclotec mill (1 mm screen; FOSS Electric, Hillerød, Denmark). They were then submitted to NIRS analysis (XDS spectrometer, FOSS Electric, Hillerød, Denmark), and the absorption data was recorded as log 1/R from 1100 to $2498 \mathrm{~nm}$, every $2 \mathrm{~nm}$ (WINISI 1.5 , FOSS Tecator Infrasoft International LCC, Hillerød, Denmark). Chemical characteristics of forage, i.e. proteins (\% DM), fibres (\% DM) according to the Van Soest method, i.e. neutral detergent fiber (NDF) and acid detergent lignin (ADL) and digestible organic matter (DOM, \% DM, cellulase method) were then estimated using the NIRS calibrations previously developed at CRA-W for hay and grass (Table 2). The correspondence between the predicted sample and the NIR spectral database was evaluated through the standardised $\mathrm{H}$ value (distance between the predicted sample and the centroid of the spectral database) according to Shenk and Westerhaus (1991). NIRS predictions were correct when averaged $\mathrm{H}$ value of predicted samples was 
Fig. 1 Schematic representation of the experimental design in Gembloux (Belgium; 50 33'45”N; 442'22'”E). Grass buffer zones were maintained to facilitate circulation and working in the experimental plots

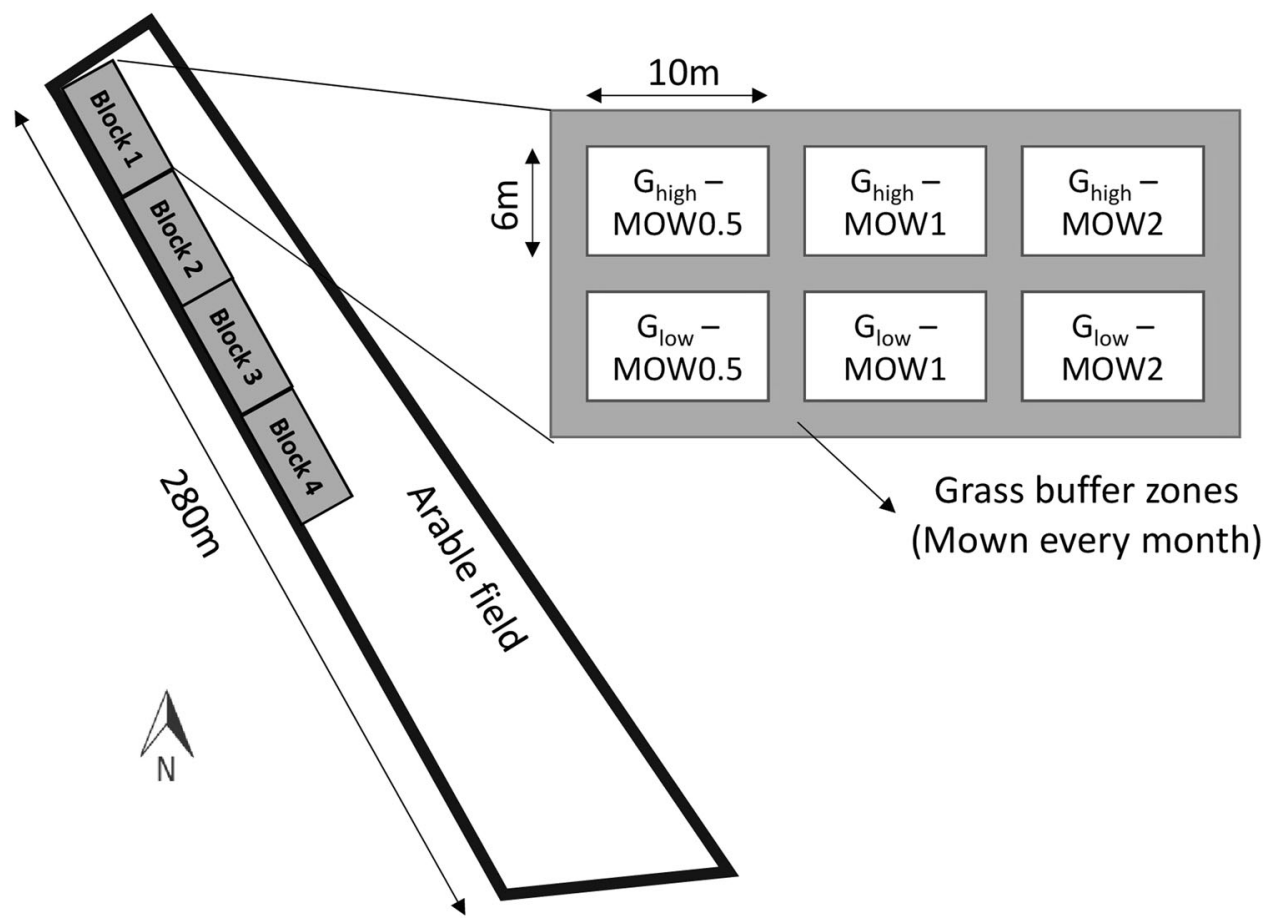

Table 2 NIRS calibration characteristics for estimating the chemical composition of wildflowers strips

\begin{tabular}{llrrllll}
\hline Constituent & $N$ & Mean & SD & Range & SEC & $R^{2}$ & SECV \\
\hline Protein (\% DM) & 3273 & 14.24 & 5.75 & $3.32-34.16$ & 0.84 & 0.98 & 0.86 \\
NDF (\% DM) & 1698 & 48.72 & 7.35 & $18.86-70.24$ & 2.02 & 0.92 & 2.05 \\
ADL (\% DM) & 1222 & 3.21 & 1.53 & $1.00-9.07$ & 0.58 & 0.86 & 0.6 \\
DOM (\% DM) & 2487 & 76.91 & 10.13 & $39.37-95.43$ & 2.34 & 0.95 & 2.38 \\
\hline
\end{tabular}

$N$ number of sample in the NIRS database, $S D$ standard deviation of the population in the NIRS database, $S E C$ standard error of calibration, $R^{2}$ coefficient of determination, $S E C V$ standard error of cross validation

lower than 3. For the MOW2 regime, retained values were the means weighted by DMY at each date (June and September).

\section{Soil Analyses}

In March 2014, at the resumption of the growing season, soil samples were collected in each experimental plot $(n=24)$ using a $2 \mathrm{~cm}$-diameter auger. Five soil samples were randomly collected at $20 \mathrm{~cm}$ of soil depth. The five soil samples were merged in a composite sample.

Mobile nitrogen $\left(\mathrm{N}-\mathrm{NO}_{3}\right)$ was measured on fresh samples sieved to $8 \mathrm{~mm}$. Concentrations were determined in a soilsolution mixture at $1: 5 \mathrm{w}: \mathrm{v}$ ratio after extraction with $\mathrm{KCl}$ $(0.1 \mathrm{~N})$ and agitation for $30 \mathrm{~min}$. After a $30 \mathrm{~min}$ decantation and subsequent filtration (filter: Whatman $\odot$ 602H1/2), nitrate was reduced into nitrite using a cadmium column. Nitrite was analysed by the modified Griess-llosvay method (Bremner 1965; Guiot 1975). All soil samples were dried at $40{ }^{\circ} \mathrm{C}$ and sieved to $2 \mathrm{~mm}$. A subsample of each sample was finely ground $(<200 \mu \mathrm{m})$ for $\mathrm{C}$ and $\mathrm{N}$ analyses. Total organic carbon $\left(\mathrm{C}_{\text {tot }}\right)$ and total nitrogen content $\left(\mathrm{N}_{\mathrm{tot}}\right)$ were measured by dry combustion (ISO10694 and ISO13878, respectively for $\mathrm{C}_{\mathrm{tot}}$ and $\mathrm{N}_{\mathrm{tot}}$ ). The available potassium $\left(\mathrm{K}_{\mathrm{av}}\right)$ and phosphorus $\left(\mathrm{P}_{\mathrm{av}}\right)$ concentrations were determined in a soilsolution mixture at a 1:5 w:v ratio after extraction with $\mathrm{CH}_{3} \mathrm{COONH}_{4}(0.5 \mathrm{M})$ and EDTA $(0.02 \mathrm{M})$ at $\mathrm{pH} 4.65$ and agitation for $30 \mathrm{~min}$ (Lakanen and Erviö 1971). The concentration of $\mathrm{K}$ was measured by flame atomic absorption spectrometry while the concentration of $\mathrm{P}$ was measured by colourimetry at $430 \mathrm{~nm}$.

\section{Data Analyses}

We tested effects of sown grass density, mowing regime, and their interaction using mixed-effects models with block as a random effect. When yearly data was available (i.e. floristic data and forage yield), year effect was included in models. Analyses were also computed for each year 
Table 3 ANOVAs for variables measured at each of the 5 years of the experiment (2010-2014)

\begin{tabular}{llllllll}
\hline Effects & & $\begin{array}{l}\text { Flowering } \\
\text { plant richness }\end{array}$ & $\begin{array}{l}\text { Plant } \\
\text { diversity }\end{array}$ & $\begin{array}{l}\text { Flowering } \\
\text { plant cover }\end{array}$ & $\begin{array}{l}\text { Weed } \\
\text { cover }\end{array}$ & $\begin{array}{l}\text { Colour } \\
\text { diversity }\end{array}$ & DMY \\
\hline Year & $F[4 ; 12]$ & $\mathbf{2 2 5 . 6 5}$ & $\mathbf{1 0 9 . 6 5}$ & $\mathbf{1 0 3 . 2}$ & $\mathbf{5 4 . 1 1}$ & $\mathbf{8 1 . 8 4}$ & $\mathbf{3 6 . 8 9}$ \\
& $P$ & $<\mathbf{0 . 0 0 1}$ & $\mathbf{< . 0 0 1}$ & $<\mathbf{0 . 0 0 1}$ & $<\mathbf{0 . 0 0 1}$ & $<\mathbf{0 . 0 0 1}$ & $<\mathbf{0 . 0 0 1}$ \\
Seed mix & $F[1 ; 3]$ & 0.07 & 0.55 & 9.63 & 0.07 & 2.66 & 0.04 \\
& $P$ & 0.804 & 0.513 & 0.053 & 0.808 & 0.201 & 0.853 \\
Mowing & $F[2 ; 6]$ & $\mathbf{1 2 . 2 1}$ & 4.95 & $\mathbf{7 . 7}$ & 1.2 & 1.88 & $\mathbf{3 8 0 . 7 2}$ \\
& $P$ & $\mathbf{0 . 0 0 8}$ & 0.054 & $\mathbf{0 . 0 2 2}$ & 0.365 & 0.233 & $<\mathbf{0 . 0 0 1}$ \\
Year*Seed mix & $F[4 ; 12]$ & 0.22 & 0.15 & 0.63 & 1.4 & 0.29 & 1.81 \\
& $P$ & 0.924 & 0.958 & 0.653 & 0.294 & 0.882 & 0.191 \\
Year*Mowing & $F[8 ; 24]$ & $\mathbf{7 . 5 1}$ & $\mathbf{3 . 3 1}$ & $\mathbf{1 0 . 2 6}$ & 1.4 & $\mathbf{3 . 5 5}$ & $\mathbf{4 6 . 5 4}$ \\
& $P$ & $<\mathbf{0 . 0 0 1}$ & $\mathbf{0 . 0 1 1}$ & $<\mathbf{0 . 0 0 1}$ & 0.248 & $\mathbf{0 . 0 0 8}$ & $<\mathbf{0 . 0 0 1}$ \\
Seed & $F[2 ; 6]$ & 0.74 & 1.73 & 1.21 & 1.45 & 2.34 & 0.86 \\
mix*Mowing & $P$ & 0.517 & 0.255 & 0.362 & 0.305 & 0.177 & 0.468 \\
Year*Seed & $F[8 ; 24]$ & 0.46 & 2.29 & 0.6 & 1.02 & $\mathbf{2 . 3 7}$ & 1.55 \\
Mix*Mowing & $P$ & 0.871 & 0.056 & 0.766 & 0.45 & $\mathbf{0 . 0 4 9}$ & 0.191 \\
\hline
\end{tabular}

Effects of year, seed mix, mowing and their interactions are provided. $F$-values, with degrees of freedom under square brackets and associated $P$-values are provided

Significant effects are in bold separately and for total (sum) forage yield values. ANOVAs were computed on mixed-effect models in order to determine effects significance. Analyses were computed using Minitab 16 (Minitab Inc.).

\section{Results}

\section{Flowering Species Response}

Our models revealed year effects $(P<0.001)$ for all tested variables where yearly data was available (Table 3 ). Concerning flowering species related variables (abundance, richness, diversity and colour diversity) interaction between year and mowing regime was significant.

Species richness was significantly influenced by mowing regime only in $2013(P<0.05$, Table 4$)$ and $2014(P<0.01$, Table 4). It tended to decrease with time, whatever the mowing regime. However, the decrease tended to be lower with increasing mowing frequency. Consequently, in the last year (2014), the species richness was the highest in MOW2 and the lowest in MOW0.5. MOW1 had an intermediate value. The response was similar for plant diversity, but to a lower extent. In 2014, it was also slightly higher for MOW2, but only with marginal significance $(0.05<P<0.1$, Table 4). Also, colour diversity responded this way. However, in this case, the highest value was observed for MOW0.5 in 2014. In 2012, the interaction between mowing regime and seed mix was significant for both colour and plant diversity $(P<0.05$, Table 4$)$. Flowering plant cover was influenced by sown grass density in the first three years
2010-2012 (Table 4), with higher values for $G_{\text {low }}$ seed mix (Table 4). In the last year (2014), difference in flowering plant cover was only due to mowing regime, with the highest value for MOW2 $(P<0.01$, Table 4$)$.

\section{Weed Cover}

Weed cover showed a yearly variation, but was not influenced by management options. It was the highest in the first year (2010). The lowest values were observed in 2011 and 2012 (0.9\% and $1.4 \%$, respectively). It then increased again in 2013 and 2014 until 9.2\% in average (Table 4), mainly due to Cirsium arvense expansion.

\section{Forage Quantity and Quality}

The mowing regime significantly influenced the forage DMY $(P<0.05$, Table 4$)$, except in the first year (2010) when a single mowing regime (once in September) was applied to all plots. Over the 5 year period, wildflower strips cut twice a year (MOW2) had the highest DM forage production compared to the low mowing rate. Grass proportion in the seed mix did not influence the forage DMY (Table 4).

As confirmed by the averaged $\mathrm{H}$ value of predicted samples lower than $3(\mathrm{H}=2,44)$, NIRS calibrations developed from hay and grass samples could be used for predicting wildflower strip characteristics. Cutting regime of wildflower strips significantly impacted the chemical characteristics and the digestibility of forage. Forage from MOW2 had a higher protein content $(P<0.001$, Table 4$)$, lower fibre content (NDF) $(P<0.001$, Table 4$)$ and lower 
Table 4 Mean values $( \pm \mathrm{SD})$ by mowing regime and by seed mix of all tested variables

\begin{tabular}{|c|c|c|c|c|c|c|c|c|}
\hline & \multicolumn{5}{|c|}{ Mean values $\pm \mathrm{SD}$} & \multicolumn{3}{|l|}{ ANOVA } \\
\hline & \multicolumn{3}{|c|}{ By mowing regime } & \multicolumn{2}{|l|}{ By seed mix } & \multirow[b]{2}{*}{ Mowing } & \multirow[b]{2}{*}{ Seed mix } & \multirow[b]{2}{*}{ Mowing*seed mix } \\
\hline & MOW0.5 & MOW1 & MOW2 & $G_{\text {high }}$ & $G_{\text {low }}$ & & & \\
\hline \multicolumn{9}{|c|}{ Flowering plant richness } \\
\hline 2010 & $12.0 \pm 0.0$ & $12.0 \pm 0.0$ & $12.0 \pm 0.0$ & $12.0 \pm 0.0$ & $12.0 \pm 0.0$ & & & \\
\hline 2011 & $9.1 \pm 0.4$ & $9.1 \pm 0.4$ & $9.3 \pm 0.5$ & $9.1 \pm 0.3$ & $9.3 \pm 0.5$ & & & \\
\hline 2012 & $7.3 \pm 0.5$ & $7.8 \pm 1.3$ & $7.8 \pm 0.9$ & $7.7 \pm 1.1$ & $7.5 \pm 0.8$ & & & \\
\hline 2013 & $6.8 \pm 0.9$ & $7.0 \pm 0.5$ & $7.8 \pm 0.5$ & $7.2 \pm 0.7$ & $7.2 \pm 0.8$ & $*$ & & \\
\hline 2014 & $4.9 \pm 1.0$ & $6.4 \pm 1.3$ & $7.0 \pm 0.8$ & $6.2 \pm 1.2$ & $6.0 \pm 1.5$ & $* *$ & & \\
\hline \multicolumn{9}{|l|}{ Plant diversity } \\
\hline 2010 & $2.31 \pm 0.07$ & $2.30 \pm 0.07$ & $2.33 \pm 0.03$ & $2.32 \pm 0.05$ & $2.31 \pm 0.07$ & & & \\
\hline 2011 & $1.93 \pm 0.10$ & $1.88 \pm 0.12$ & $1.93 \pm 0.15$ & $1.94 \pm 0.11$ & $1.88 \pm 0.12$ & & & \\
\hline 2012 & $1.56 \pm 0.14$ & $1.49 \pm 0.13$ & $1.46 \pm 0.12$ & $1.52 \pm 0.14$ & $1.49 \pm 0.12$ & & & $*$ \\
\hline 2013 & $1.26 \pm 0.24$ & $1.28 \pm 0.14$ & $1.53 \pm 0.11$ & $1.38 \pm 0.17$ & $1.34 \pm 0.25$ & & & \\
\hline 2014 & $1.04 \pm 0.22$ & $1.07 \pm 0.23$ & $1.27 \pm 0.19$ & $1.14 \pm 0.17$ & $1.11 \pm 0.28$ & $\circ$ & & \\
\hline \multicolumn{9}{|c|}{ Flowering plant cover $[\%]$} \\
\hline 2010 & $116.6 \pm 12.7$ & $121.0 \pm 21.0$ & $124.5 \pm 13.9$ & $112.5 \pm 14.5$ & $128.9 \pm 13.2$ & & $*$ & \\
\hline 2011 & $79.0 \pm 11.4$ & $86.4 \pm 16.8$ & $78.1 \pm 22.3$ & $72.3 \pm 13.0$ & $90.0 \pm 16.4$ & & $\circ$ & \\
\hline 2012 & $81.0 \pm 10.9$ & $83.1 \pm 13.9$ & $76.3 \pm 11.3$ & $74.5 \pm 12.2$ & $85.8 \pm 9.0$ & & $*$ & \\
\hline 2013 & $43.0 \pm 9.4$ & $46.8 \pm 10.1$ & $53.8 \pm 13.7$ & $45.8 \pm 12.7$ & $49.9 \pm 10.7$ & & & \\
\hline 2014 & $42.9 \pm 12.1$ & $53.2 \pm 21.6$ & $86.6 \pm 15.4$ & $54.2 \pm 20.2$ & $67.5 \pm 28.2$ & $* *$ & & \\
\hline \multicolumn{9}{|l|}{ Weed cover } \\
\hline 2010 & $34.9 \pm 18.1$ & $28.5 \pm 15.5$ & $28.3 \pm 10.4$ & $33.1 \pm 16.4$ & $28 \pm 12.9$ & & & \\
\hline 2011 & $0.7 \pm 0.6$ & $0.8 \pm 0.6$ & $1.3 \pm 2.9$ & $1.3 \pm 2.3$ & $0.5 \pm 0.6$ & & & \\
\hline 2012 & $2.0 \pm 1.8$ & $1.8 \pm 2.4$ & $0.4 \pm 0.4$ & $1.3 \pm 1.8$ & $1.6 \pm 1.9$ & & & \\
\hline 2013 & $5.4 \pm 5.5$ & $2.8 \pm 3.1$ & $1.7 \pm 1.0$ & $2.3 \pm 2.1$ & $4.3 \pm 5.0$ & & & \\
\hline 2014 & $14.0 \pm 11.4$ & $5.6 \pm 5.5$ & $8.1 \pm 3.2$ & $7.8 \pm 4.8$ & $10.7 \pm 10.4$ & & & \\
\hline \multicolumn{9}{|l|}{ Colour diversity } \\
\hline 2010 & $1.58 \pm 0.07$ & $1.57 \pm 0.06$ & $1.60 \pm 0.02$ & $1.60 \pm 0.02$ & $1.56 \pm 0.07$ & & & \\
\hline 2011 & $1.18 \pm 0.02$ & $1.10 \pm 0.07$ & $1.15 \pm 0.06$ & $1.14 \pm 0.07$ & $1.14 \pm 0.06$ & & & \\
\hline 2012 & $1.00 \pm 0.21$ & $1.10 \pm 0.11$ & $1.05 \pm 0.10$ & $1.09 \pm 0.15$ & $1.01 \pm 0.15$ & & & $*$ \\
\hline 2013 & $0.91 \pm 0.12$ & $0.88 \pm 0.08$ & $0.95 \pm 0.10$ & $0.94 \pm 0.09$ & $0.88 \pm 0.1$ & & & \\
\hline 2014 & $0.91 \pm 0.16$ & $0.67 \pm 0.14$ & $0.72 \pm 0.20$ & $0.78 \pm 0.14$ & $0.75 \pm 0.24$ & $*$ & & \\
\hline \multicolumn{9}{|l|}{ DMY $\left[10^{3} \mathrm{~kg} / \mathrm{ha}\right]$} \\
\hline 2010 & $3.8 \pm 0.3$ & $3.9 \pm 0.4$ & $4.0 \pm 0.3$ & $4.0 \pm 0.3$ & $3.9 \pm 0.4$ & & & \\
\hline 2011 & - & $5.4 \pm 1.0$ & $8.3 \pm 2.0$ & $7.0 \pm 1.9$ & $6.7 \pm 2.5$ & $* *$ & & \\
\hline 2012 & $6.0 \pm 1.1$ & $6.9 \pm 0.6$ & $9.5 \pm 0.6$ & $7.2 \pm 1.7$ & $7.8 \pm 1.7$ & $* * *$ & & \\
\hline 2013 & - & $4.7 \pm 0.7$ & $9.7 \pm 0.9$ & $7.1 \pm 2.4$ & $7.3 \pm 3.1$ & $* *$ & & \\
\hline 2014 & $5.0 \pm 1.1$ & $4.2 \pm 0.6$ & $6.0 \pm 0.7$ & $5.2 \pm 0.9$ & $4.9 \pm 1.3$ & $*$ & & \\
\hline Sum & $14.8 \pm 1.8$ & $25.1 \pm 1.5$ & $37.5 \pm 2.6$ & $25.7 \pm 9.3$ & $25.9 \pm 10.4$ & $* * *$ & & \\
\hline Proteins [\%] & $8.0 \pm 0.9$ & $7.1 \pm 0.6$ & $10.3 \pm 0.8$ & $8.1 \pm 1.5$ & $8.9 \pm 1.6$ & $* * *$ & & \\
\hline NDF [\%] & $55.7 \pm 1.4$ & $56.1 \pm 1.1$ & $45.8 \pm 1.3$ & $53.0 \pm 5.1$ & $52.0 \pm 5.1$ & $* * *$ & & \\
\hline ADL $[\%]$ & $7.7 \pm 0.6$ & $7.7 \pm 0.3$ & $6.1 \pm 0.1$ & $7.2 \pm 0.9$ & $7.1 \pm 0.9$ & $* *$ & & \\
\hline DOM [\%] & $49.8 \pm 3.5$ & $50.0 \pm 1.9$ & $61.4 \pm 0.8$ & $53.1 \pm 6.4$ & $54.4 \pm 5.7$ & $* * *$ & & \\
\hline $\mathrm{N}_{\text {tot }}[\%]$ & $0.119 \pm 0.004$ & $0.119 \pm 0.005$ & $0.121 \pm 0.003$ & $0.119 \pm 0.006$ & $0.12 \pm 0.003$ & & & \\
\hline $\mathrm{N}-\mathrm{NO}_{3}[\mathrm{mg} / \mathrm{kg}]$ & $0.264 \pm 0.083$ & $0.251 \pm 0.391$ & $0.331 \pm 0.209$ & $0.262 \pm 0.211$ & $0.302 \pm 0.295$ & & & \\
\hline $\mathrm{P}_{\mathrm{av}}[\mathrm{mg} / 100 \mathrm{~g}]$ & $30 \pm 3.2$ & $30.2 \pm 1.7$ & $28.7 \pm 1.4$ & $29.5 \pm 2.2$ & $29.7 \pm 2.4$ & & & \\
\hline
\end{tabular}


Table 4 (continued)

\begin{tabular}{|c|c|c|c|c|c|c|c|c|}
\hline & \multicolumn{5}{|c|}{ Mean values $\pm \mathrm{SD}$} & \multirow{2}{*}{\multicolumn{3}{|c|}{ ANOVA }} \\
\hline & \multicolumn{3}{|c|}{ By mowing regime } & \multicolumn{2}{|l|}{ By seed mix } & & & \\
\hline & MOW0.5 & MOW1 & MOW2 & $G_{\text {high }}$ & $G_{\text {low }}$ & Mowing & Seed mix & Mowing*seed mix \\
\hline $\mathrm{K}_{\mathrm{av}}[\mathrm{mg} / 100 \mathrm{~g}]$ & $29.2 \pm 2.2$ & $27.7 \pm 4.1$ & $23.8 \pm 1.2$ & $26.9 \pm 3.4$ & $26.8 \pm 3.8$ & $*$ & & \\
\hline $\mathrm{C}_{\text {tot }}[\mathrm{g} / \mathrm{kg}]$ & $15.8 \pm 1.7$ & $16.5 \pm 2.3$ & $15.6 \pm 1.2$ & $15.8 \pm 2$ & $16.1 \pm 1.6$ & & & \\
\hline
\end{tabular}

Yearly values are displayed when available. ANOVA is the result of ANOVAs made on mixed-effect models (with Block as random grouping effect). Different letters indicate significant differences. For weed cover, different letters indicate significant difference in mean values for each year. DMY data were not available for MOW0.5 in 2011 and 2013 due to absence of mowing

$D M Y$ dry matter yield, $N D F$ neutral detergent fiber, $A D L$ acid detergent lignin, $D O M$ digestible organic matter

$* * * P<0.001 ; * * 0.01>P>0.001 ; * 0.05>P>0.01 ;{ }^{\circ} 0.1>P>0.05$; not displayed: $P>0.1$

indigestible fibre content (ADL) $(P<0.01$, Table 4). Finally, the digestible organic matter (DOM) was significantly higher in MOW2 than in MOW0.5 and MOW1 $(P<0.001$, Table 4$)$. As in the case of DMY, decreasing the proportion of grass seeds in the seed mixture did not influence the chemical composition of the forage.

\section{Soil Nutrients}

Plots with the highest mowing rate tended to experience a $\mathrm{K}_{\mathrm{av}}$ depletion. For this nutrient, we observed contents varying from $23.8 \mathrm{mg} / 100 \mathrm{~g}$ in MOW2 to $27.7 \mathrm{mg} / 100 \mathrm{~g}$ in MOW1 $29.2 \mathrm{mg} / 100 \mathrm{~g}$ in MOW0.5 $(P<0.05$, Table 4$)$. None of the other soil variables were affected by management options.

\section{Discussion}

\section{Grass Seed Density Effect}

Our study revealed effects of grass seed density on flowering plant abundance in the first three years, with a higher flower cover in the seed mix with reduced grass proportion. This was primarily due to improved development of the legumes Lotus corniculatus and Trifolium pratense during the first years after strip implementation (Table 5). This is congruent with the general low competitive ability of legumes under eutrophic conditions (Zanetti et al. 1996). However, this was not observed beyond the fourth year after sowing, as mowing regime effects became more and more pronounced and overwhelmed initial sowing conditions. No effect was found on colour and species diversities. It was previously shown by Staab et al. (2015) that detrimental effect of grass on flower species diversity appeared when grass biomass proportion is higher than $90 \%$. In our case, it is likely that this threshold was not reached even with our higher grass density.
Contrarily to our initial assumption, grasses did not hamper noxious weed, as weed cover was not significantly influenced by grass proportion in the seed mix. Earlier studies on weed suppression by flower strips showed that weeds only overdevelop in the case of spontaneous unsown flower strips, while sown flower strips efficiently cover the soil against weeds (Denys and Tscharntke 2002; De Cauwer et al. 2008). After the third year, such a conclusion could have been driven from our experience, as annual weed emergence on the first year was rapidly pulled up to a ca. $1 \%$ weed cover. However, from the fourth year, weed cover increased again to $\sim 10 \%$ on average on the fifth year, i.e. the end of AES commitment. This was moreover mainly due to C. arvense, a particularly pernicious species that is likely to spread into arable fields where it is difficult to control (Tiley 2010). This rather high cover level is therefore likely to discourage farmers from continuing with their implemented flower strips.

\section{Mowing Effect}

Colour diversity, reflecting potential for landscape aesthetics (Junge et al. 2015), was the highest under the MOW0.5 mowing regime after 5 years of application. A tradeoff is therefore observed with flower abundance and richness that were the lowest under this mowing regime. The highest values for these variables were observed under the twice-a-year mowing regime. $T$. pratense was one of the main drivers for this pattern, as it responded the best to the MOW2 regime (Table 5). This result is particularly relevant as this species is considered to be a keystone species for bumblebee conservation in Europe and could facilitate the pollination of wild and cultivated plants (Kleijn and Raemakers 2008; Rundlöf et al. 2014).

The increased abundance of this species in the MOW2 regime may also partly explain the better forage quality in those plots. Of course, it is well known that digestibility correlates positively with the utilisation frequency, either 
Table 5 Mean species cover each year, by mowing regime and by seed mix

\begin{tabular}{|c|c|c|c|c|c|c|}
\hline & \multirow[t]{3}{*}{ Year } & \multicolumn{5}{|c|}{ Species cover } \\
\hline & & \multicolumn{3}{|c|}{ By mowing regime } & \multicolumn{2}{|c|}{ By seed mix } \\
\hline & & MOW0.5 & MOW1 & MOW2 & $\overline{G_{\text {high }}}$ & $G_{\text {low }}$ \\
\hline \multirow[t]{5}{*}{ Achillea millefolium $\mathrm{L}$. } & 2010 & 4.50 & 4.68 & 4.92 & 5.12 & 4.28 \\
\hline & 2011 & 5.15 & 5.58 & 4.17 & 6.24 & 3.69 \\
\hline & 2012 & 8.93 & 9.79 & 6.21 & 7.07 & 9.55 \\
\hline & 2013 & 8.41 & 11.15 & 13.80 & 10.79 & 11.45 \\
\hline & 2014 & 2.03 & 4.25 & 11.86 & 5.75 & 6.35 \\
\hline \multirow[t]{5}{*}{ Centaurea cyanus L. } & 2010 & 13.44 & 13.57 & 12.57 & 12.50 & 13.88 \\
\hline & 2011 & 0.13 & 0.06 & 0.10 & 0.01 & 0.18 \\
\hline & 2012 & 0.00 & 0.00 & 0.00 & 0.00 & 0.00 \\
\hline & 2013 & 0.00 & 0.00 & 0.00 & 0.00 & 0.00 \\
\hline & 2014 & 0.00 & 0.00 & 0.00 & 0.00 & 0.00 \\
\hline \multirow{5}{*}{$\begin{array}{l}\text { Centaurea } \\
\text { jacea } \mathrm{L} .\end{array}$} & 2010 & 6.73 & 7.25 & 6.94 & 7.11 & 6.83 \\
\hline & 2011 & 4.56 & 5.73 & 5.17 & 5.42 & 4.89 \\
\hline & 2012 & 24.58 & 30.40 & 20.60 & 23.90 & 26.49 \\
\hline & 2013 & 22.94 & 24.77 & 13.88 & 19.28 & 21.78 \\
\hline & 2014 & 25.40 & 30.96 & 19.15 & 24.68 & 25.65 \\
\hline \multirow{5}{*}{$\begin{array}{l}\text { Daucus } \\
\text { carota } \mathrm{L} .\end{array}$} & 2010 & 8.15 & 6.96 & 7.53 & 6.75 & 8.34 \\
\hline & 2011 & 4.73 & 4.85 & 5.33 & 4.67 & 5.28 \\
\hline & 2012 & 1.06 & 0.21 & 0.46 & 0.53 & 0.63 \\
\hline & 2013 & 1.61 & 0.59 & 0.26 & 0.62 & 1.03 \\
\hline & 2014 & 0.20 & 0.07 & 0.48 & 0.18 & 0.33 \\
\hline \multirow[t]{5}{*}{ Glebionis segetum } & 2010 & 11.56 & 11.96 & 11.73 & 11.85 & 11.65 \\
\hline & 2011 & 0.00 & 0.00 & 0.00 & 0.00 & 0.00 \\
\hline & 2012 & 0.00 & 0.00 & 0.00 & 0.00 & 0.00 \\
\hline & 2013 & 0.00 & 0.00 & 0.00 & 0.00 & 0.00 \\
\hline & 2014 & 0.00 & 0.00 & 0.00 & 0.00 & 0.00 \\
\hline \multirow{5}{*}{$\begin{array}{l}\text { Leucanthemum } \\
\text { vulgare Lam. }\end{array}$} & 2010 & 4.49 & 4.67 & 4.73 & 4.77 & 4.49 \\
\hline & 2011 & 10.29 & 13.92 & 8.04 & 9.79 & 11.71 \\
\hline & 2012 & 17.62 & 15.73 & 16.40 & 15.57 & 17.60 \\
\hline & 2013 & 0.00 & 0.00 & 0.00 & 0.00 & 0.00 \\
\hline & 2014 & 0.00 & 0.06 & 0.00 & 0.00 & 0.04 \\
\hline \multirow[t]{5}{*}{ Lotus corniculatus L. } & 2010 & 11.46 & 10.55 & 11.25 & 7.48 & 14.69 \\
\hline & 2011 & 15.75 & 13.31 & 14.42 & 9.68 & 19.31 \\
\hline & 2012 & 6.79 & 16.61 & 25.47 & 15.16 & 17.42 \\
\hline & 2013 & 0.81 & 0.74 & 1.50 & 1.13 & 0.90 \\
\hline & 2014 & 0.13 & 0.54 & 1.15 & 0.65 & 0.56 \\
\hline \multirow{5}{*}{$\begin{array}{l}\text { Malva } \\
\text { moschata L. }\end{array}$} & 2010 & 2.65 & 2.11 & 2.78 & 2.50 & 2.53 \\
\hline & 2011 & 1.98 & 1.48 & 1.65 & 1.85 & 1.56 \\
\hline & 2012 & 5.81 & 2.19 & 0.58 & 3.04 & 2.69 \\
\hline & 2013 & 2.96 & 1.95 & 0.28 & 1.64 & 1.82 \\
\hline & 2014 & 6.71 & 1.59 & 0.70 & 2.88 & 3.12 \\
\hline \multirow[t]{5}{*}{ Medicago lupulina $\mathrm{L}$. } & 2010 & 18.65 & 18.57 & 18.19 & 17.06 & 19.88 \\
\hline & 2011 & 9.90 & 11.25 & 11.31 & 10.24 & 11.40 \\
\hline & 2012 & 0.00 & 0.07 & 0.13 & 0.09 & 0.04 \\
\hline & 2013 & 0.06 & 0.00 & 5.96 & 2.71 & 1.31 \\
\hline & 2014 & 0.00 & 0.58 & 6.65 & 1.73 & 3.10 \\
\hline \multirow[t]{7}{*}{ Papaver rhoeas L. } & 2010 & 15.52 & 17.44 & 18.13 & 17.72 & 16.33 \\
\hline & 2011 & 0.00 & 0.00 & 0.00 & 0.00 & 0.00 \\
\hline & 2012 & 0.00 & 0.20 & 0.06 & 0.09 & 0.09 \\
\hline & 2013 & 0.00 & 0.07 & 0.00 & 0.04 & 0.00 \\
\hline & 2014 & 0.00 & 0.07 & 0.00 & 0.00 & 0.04 \\
\hline & 2010 & 6.33 & 7.79 & 8.73 & 6.26 & 8.97 \\
\hline & 2011 & 5.77 & 6.69 & 5.52 & 5.44 & 6.54 \\
\hline
\end{tabular}

Table 5 (continued)

\begin{tabular}{|c|c|c|c|c|c|c|}
\hline & \multirow[t]{3}{*}{ Year } & \multicolumn{5}{|c|}{ Species cover } \\
\hline & & \multicolumn{3}{|c|}{ By mowing regime } & \multicolumn{2}{|c|}{ By seed mix } \\
\hline & & MOW0.5 & MOW1 & MOW2 & $G_{\text {high }}$ & $G_{\text {low }}$ \\
\hline \multirow{2}{*}{$\begin{array}{l}\text { Silene latifolia subsp. } \\
\text { alba (Mill.) Greuter } \\
\& \text { Burdet }\end{array}$} & $\begin{array}{l}2012 \\
2013\end{array}$ & $\begin{array}{l}16.24 \\
5.83\end{array}$ & $\begin{array}{l}7.93 \\
5.48\end{array}$ & $\begin{array}{l}4.90 \\
3.28\end{array}$ & $\begin{array}{l}8.79 \\
4.64\end{array}$ & $\begin{array}{l}10.59 \\
5.08\end{array}$ \\
\hline & 2014 & 8.44 & 4.36 & 2.53 & 4.47 & 5.76 \\
\hline \multirow[t]{5}{*}{ Trifolium pratense $\mathrm{L}$. } & 2010 & 13.08 & 15.44 & 17.06 & 13.42 & 16.98 \\
\hline & 2011 & 20.73 & 23.52 & 22.38 & 18.94 & 25.47 \\
\hline & 2012 & 0.00 & 0.00 & 1.48 & 0.32 & 0.67 \\
\hline & 2013 & 0.39 & 2.03 & 14.86 & 4.99 & 6.53 \\
\hline & 2014 & 0.00 & 10.65 & 44.04 & 13.89 & 22.57 \\
\hline \multirow[t]{5}{*}{ Festuca rubra $\mathrm{L}$. } & 2010 & n.a. & n.a. & n.a. & n.a. & n.a. \\
\hline & 2011 & 29.44 & 22.48 & 32.21 & 43.03 & 13.06 \\
\hline & 2012 & 37.30 & 36.56 & 47.70 & 49.33 & 31.72 \\
\hline & 2013 & 48.15 & 49.94 & 70.56 & 66.19 & 46.24 \\
\hline & 2014 & 52.77 & 56.63 & 64.56 & 67.04 & 48.93 \\
\hline \multirow[t]{5}{*}{ Poa pratensis L. } & 2010 & n.a. & n.a. & n.a. & n.a. & n.a. \\
\hline & 2011 & 1.69 & 1.46 & 1.42 & 1.88 & 1.17 \\
\hline & 2012 & 0.42 & 0.62 & 0.51 & 0.14 & 0.88 \\
\hline & 2013 & 3.96 & 5.70 & 0.94 & 3.56 & 3.50 \\
\hline & 2014 & 2.59 & 9.71 & 5.36 & 3.23 & 8.55 \\
\hline \multirow[t]{5}{*}{ Agrostis capillaris L. } & 2010 & n.a. & n.a. & n.a. & n.a. & n.a. \\
\hline & 2011 & 2.21 & 2.44 & 2.19 & 2.94 & 1.61 \\
\hline & 2012 & 0.26 & 0.24 & 0.14 & 0.14 & 0.29 \\
\hline & 2013 & 3.57 & 3.01 & 0.02 & 0.50 & 3.90 \\
\hline & 2014 & 13.95 & 11.98 & 1.17 & 4.52 & 13.54 \\
\hline
\end{tabular}

mowing or grazing (Gardarin et al. 2014). Also, the stage of maturity of individual species when forages are mown, can explain the difference in digestibility (Bruinenberg et al. 2002). However, most species in our study, including the dominant Festuca rubra, belong to the plant functional type (PFT) $\mathrm{C}$ according to the classification proposed by Cruz et al. (2002). That type is characterised by low digestibility values in the beginning of the growing season but a slower decline during the growth of the plant. Therefore, overmaturity may be only part of the explanation for the difference in forage quality, species composition being another one. Trifolium pratense is known for its participation in DMY (De Cauwer et al. 2006a) and is frequently used in hay meadows with multi-cut management (Halling et al. 2004). Its digestibility is commonly high and less dependent on the ageing of the plant. Moreover, dicotyledonous species, that had higher cover in the MOW2 plots, have lower NDF content and higher pectin content, resulting in better digestibility (Bruinenberg et al. 2002). Forage production is not the main aim of wildflower strips. However, it may lead to a better integration of AES within usual farming procedures, and therefore make AES more acceptable (Sattler and Nagel 2010).

Concerning the soil variables, we only found that mowing regime influenced $\mathrm{K}$ availability, in the sense of an increased $\mathrm{K}$ depletion with increasing biomass exportation, 
i.e. the MOW2 regime. Plant offtake plays a major role in $\mathrm{K}$ cycle. Repeated mowing without $\mathrm{K}$ supply is likely to provoke a $\mathrm{K}$ depletion within 3-10 years (Kayser and Isselstein 2005). For other soil variables, installation of flower strips and subsequent biomass exportation through mowing did not result in a clear soil nutrient depletion. It is well known from ecological restoration literature that repeated biomass exportation is unlikely to rapidly reduce availability of these nutrients in the soil (Marrs 1993; Walker et al. 2004; Piqueray and Mahy 2010). In case of conversion from arable land to grassland, $\mathrm{P}$ uptake from mowing can fail at diminishing plant-available $\mathrm{P}$, as it can be replaced through mineralisation from larger nonavailable pools (Walker et al. 2004). $\mathrm{P}_{\mathrm{av}}$ content in our study site (ca. $30 \mathrm{mg} / 100 \mathrm{~g}$ ) was far higher than the $5 \mathrm{mg} /$ $100 \mathrm{~g}$ considered as the upper limit for maintaining speciesrich grasslands in semi-natural systems (Janssens et al. 1998). We indeed observed a decrease in species richness and flower cover over the 5 years of the experiment, that was limited through multiple mowing. This confirms the need for a rather early mowing date to maintain flowering plant species under fertile conditions (Kirmer et al. 2018).

\section{Conclusions and implications for management}

Accordingly to our assumptions, mowing twice a year (in late June and in September) resulted in the most interesting option. It permitted enhancement of flowering plant cover and resulted in better forage production, both in quantity and quality. We showed that this option would likely contribute to decreased $\mathrm{K}$ availability in soils, but did not have an impact on other soil nutrients over 5 years. This option should therefore be promoted in wildflower management and was therefore accepted as an alternative management option in Walloon AES following this study. One can argue that a first mowing in late June, at the end of the flowering peak, may be a problem for insect conservation. However, a meta-analysis by Humbert et al. (2012b) revealed that there was generally minimal advantage of delaying the first mowing date beyond early summer in grasslands. Also, several species are able to regrow after late June-mowing, and therefore extend flower availability in late summer (Kirmer et al. 2018). However, there is a great amount of evidence that keeping unmown refuges is of primary importance for insect conservation in grasslands (Humbert et al. 2012a; Lebeau et al. 2015) and therefore probably in grassland-like wildflower strips too. Such zones were efficient at preserving insects as well as insect-mediated ecosystem services (Buri et al. 2014). Therefore, maintaining an unmown refuge zone of $\min$. 3-m width all along the wildflower strips was retained as compulsory management in Wallonia (southern Belgium). In case of a second mowing, the refuge zone of the first mowing has to be maintained or enlarged in order to keep a less disturbed overwintering zone (Schmidt et al. 2008). However, it is recommended that it be moved annually within the wildflower strip in order to avoid species richness decrease due to management abandonment (Schmidt et al. 2008; Uchida and Ushimaru 2014). Mowing regime options other than twice-a-year should not be completely rejected as, with the exception of forage production aspects, they were valuable regarding the tested variables. They can therefore be advantageous in farms without livestock, which is increasingly the case in cropland regions where wildflower strips are often implemented.

None of our hypotheses regarding weed control were verified. Their relative abundance in the first year was due to annual weeds from the soil seed bank. Indeed, soil seed bank is usually dense in arable lands and mainly depends on the former management such as crop rotation or herbicide use (Asteraki et al. 2004; Albrecht 2005). Their emergence in wildflower strips mainly relies on the capacity of sown species to outcompete them (Asteraki et al. 2004; De Cauwer et al. 2008), which was the case in our study in the second and third year. From the fourth year, neither increasing grass seed density nor mowing frequency resulted in a decrease of weed cover. Regardless of the treatment, wildflower tended to shelter noxious weeds after 5 years, notably the thistle Cirsium arvense. This supports the need to test the efficacy of specific management practices such as selective clipping or spraying, both being allowed in the Walloon AES.

Acknowledgements The authors acknowledge Dirk Verhulst and Marie Legast for the implantation and management of the experiment. Natagriwal is a non-for-profit association funded by the Walloon government.

\section{Compliance with ethical standards}

Conflict of Interest The authors declare that they have no conflict of interest.

Publisher's note: Springer Nature remains neutral with regard to jurisdictional claims in published maps and institutional affiliations.

\section{References}

Albrecht H (2005) Development of arable weed seedbanks during the 6 years after the change from conventional to organic farming. Weed Res 45:339-350. https://doi.org/10.1111/j.1365-3180. 2005.00472.x

Asteraki EJ, Hart BJ, Ings TC, Manley WJ (2004) Factors influencing the plant and invertebrate diversity of arable field margins Agric Ecosyst Environ. 102:219-231. https://doi.org/10.1016/j.agee. 2003.07.003

Batáry P, Dicks LV, Kleijn D, Sutherland WJ (2015) The role of agrienvironment schemes in conservation and environmental 
management. Conserv Biol 29:1006-1016. https://doi.org/10. 1111/cobi.12536

Bremner JM (1965) Inorganic Forms of Nitrogen. In: Black CA (Ed.) Methods of soils analysis. Part2. American Society of Agronomy, Madison, WI, USA, pp 1179-1237

Bruinenberg MH, Valk H, Korevaar H, Struik PC (2002) Factors affecting digestibility of temperate forages from seminatural grasslands: a review. Grass Forage Sci 57:292-301

Buri P, Humbert JY, Arlettaz R (2014) Promoting pollinating insects in intensive agricultural matrices: field-scale experimental manipulation of hay-meadow mowing regimes and its effects on bees. PLoS ONE 9:e85635. https://doi.org/10.1371/journal.pone.0085635

Critchley CNR, Chambers BJ, Fowbert JA, Bhogal A, Rose SC, Sanderson RA (2002) Plant species richness, functional type and soil properties of grasslands and allied vegetation in English Environmentally Sensitive Areas. Grass Forage Sci 57:82-92. https://doi.org/10.1046/j.1365-2494.2002.00305.x

Cruz P, Duru M, Therond O, Theau JP, Ducourtieux C (2002) Une nouvelle approche pour caractériser les prairies naturelles et leur valeur d' usage. Fourragees 172:335-354

De Cauwer B, Reheul D, Nijs I, Milbau A (2006a) Dry matter yield and herbage quality of field margin vegetation as a function of vegetation development and management regime. NJAS - Wagening J Life Sci 54:37-60. https://doi.org/10.1016/S1573-5214 (06)80003-5

De Cauwer B, Reheul D, Nijs I, Milbau A (2006b) Effect of margin strips on soil mineral nitrogen and plant biodiversity. Agron Sustain Dev 26:117-126. https://doi.org/10.1051/agro:2006004

De Cauwer B, Reheul D, Nijs I, Milbau A (2008) Management of newly established field margins on nutrient-rich soil to reduce weed spread and seed rain into adjacent crops. Weed Res 48:102-112. https://doi.org/10.1111/j.1365-3180.2007.00607.x

Denys C, Tscharntke T (2002) Plant-insect communities and predatorprey ratios in field margin strips, adjacent crop fields, and fallows. Oecologia 130:315-324. https://doi.org/10.1007/s004420100796

Ebeling A, Klein AM, Schumacher J, Weisser WW, Tscharntke T (2008) How does plant richness affect pollinator richness and temporal stability of flower visits? Oikos 117:1808-1815. https:// doi.org/10.1111/j.1600-0706.2008.16819.x

Fründ J, Linsenmair KE, Blüthgen N (2010) Pollinator diversity and specialization in relation to flower diversity. Oikos 119:1581-1590. https://doi.org/10.1111/j.1600-0706.2010.18450.x

Gardarin A, Garnier É, Carrère P et al. (2014) Plant trait-digestibility relationships across management and climate gradients in permanent grasslands. J Appl Ecol 51:1207-1217. https://doi.org/10. $1111 / 1365-2664.12293$

Guiot J (1975) Estimation des reserves azotees du sol par determination de l'azote mineral. Rev l'Agriculture 28:1117-1132

Haaland C, Naisbit RE, Bersier LF (2011) Sown wildflower strips for insect conservation: a review. Insect Conserv Divers 4:60-80. https://doi.org/10.1111/j.1752-4598.2010.00098.x

Halling MA, Topp CFE, Doyle CJ (2004) Aspects of the productivity of forage legumes in Northern Europe. Grass Forage Sci 59:331-344. https://doi.org/10.1111/j.1365-2494.2004.00435.x

Hansson M, Fogelfors H (1998) Management of permanent set-aside on arable land in Sweden. J Appl Ecol 35:758-771. https://doi. org/10.1046/j.1365-2664.1998.355350.x

Hatt S, Uyttenbroeck R, Lopes T, Mouchon P, Chen J, Piqueray J, Monty A, Francis F (2017) Do flower mixtures with high functional diversity enhance aphid predators in wildflower strips? Eur J Entomol 114:66-76. https://doi.org/10.14411/eje.2017.010

Hatt S, Uyttenbroeck R, Lopes T, Chen JL, Piqueray J, Monty A, Francis F (2018) Effect of flower traits and hosts on the abundance of parasitoids in perennial multiple species wildflower strips sown within oilseed rape (Brassica napus) crops. Arthropod
Plant Interact 12:787-797. https://doi.org/10.1007/s11829-0179567-8

Humbert JY, Ghazoul J, Richner N, Walter T (2012a) Uncut grass refuges mitigate the impact of mechanical meadow harvesting on orthopterans. Biol Conserv 152:96-101. https://doi.org/10.1016/j. biocon.2012.03.015

Humbert JY, Pellet J, Buri P, Arlettaz R (2012b) Does delaying the first mowing date benefit biodiversity in meadowland? Environ Evid 1:9

Janssens F, Peeters A, Tallowin JRB, Bakker JP, Bekker RM, Fillat F, Oomes MJM (1998) Relationship between soil chemical factors and grassland diversity. Plant Soil 202:69-78. https://doi.org/10. 1023/A:1004389614865

Junge X, Schüpbach B, Walter T, Schmid B, Lindemann-Matthies P (2015) Aesthetic quality of agricultural landscape elements in different seasonal stages in Switzerland. Landsc Urban Plan 133:67-77. https://doi.org/10.1016/j.landurbplan.2014.09.010

Kahmen S, Poschlod P, Schreiber KF (2002) Conservation management of calcareous grasslands. Changes in plant species composition and response of functional traits during 25 years. Biol Conserv 104:319-328. https://doi.org/10.1016/S0006-3207(01) 00197-5

Kayser M, Isselstein J (2005) Potassium cycling and losses in grassland systems: a review. Grass Forage Sci 60:213-224

Kiehl K, Pfadenhauer J (2007) Establishment and persistence of target species in newly created calcareous grasslands on former arable fields. Plant Ecol 189:31-48. https://doi.org/10.1007/s11258-0069164-X

Kirmer A, Rydgren K, Tischew S (2018) Smart management is key for successful diversification of field margins in highly productive farmland. Agric Ecosyst Environ 251:88-98. https://doi.org/10. 1016/j.agee.2017.09.028

Kleijn D, Raemakers I (2008) A retrospective analysis of pollen host plant use by stable and declining bumble bee species. Ecology 89:1811-1823. https://doi.org/10.1890/07-1275.1

Lakanen E, Erviö R (1971) A comparison of eight extractants for the determination of plant available micronutrients in soils. Acta Agric Fenn 123:223-232

Landis DA, Wratten SD, Gurr GM (2000) Habitat Management to Conserve Natural Enemies of Arthropod Pests in Agriculture. Annu Rev Entomol 45:175-201. https://doi.org/10.1146/annurev. ento. 45.1 .175

Lebeau J, Wesselingh RA, Van Dyck H (2015) Butterfly density and behaviour in uncut hay meadow strips: behavioural ecological consequences of an agri-environmental scheme. PLoS ONE 10: e0134945. https://doi.org/10.1371/journal.pone.0134945

Marrs RH (1993) Soil fertility and nature conservation in Europe: theorical considerations and practical management solutions. In: Begon M, Fitter AH (eds) Advances in ecological research 24. Harcourt Brace \& Company, London, pp 241-300

Marrs AJO, Lakhani KH, Kirkham FW, Ecology A (2016) Experimental assessment of the effects of nitrogen addition under haycutting and aftermath grazing on the vegetation of meadows on a Somerset Peat Moor. J Appl Ecol 30:321-332

Nicholls CI, Altieri MA (2013) Plant biodiversity enhances bees and other insect pollinators in agroecosystems. A review. Agron Sustain Dev 33:257-274. https://doi.org/10.1007/s13593-012-0092-y

Oelmann Y, Kreutziger Y, Temperton VM, Buchmann N, Roscher C, Schumacher J, Schulze E-D, Weisser WW, Wilcke W (2007) Nitrogen and phosphorus budgets in experimental grasslands of variable diversity. J Environ Qual 36:396. https://doi.org/10. 2134/jeq2006.0217

Piqueray J, Mahy G (2010) Revue bibliographique sur la restauration des pelouses calcicoles en Europe: Contraintes rencontrées et solutions proposes. Biotechnol Agron Soc Environ 14:471-484 
Piqueray J, Rouxhet S, Hendrickx S, Mahy G (2016) Changes in the vegetation of hay meadows under an agri-environment scheme in South Belgium. Conserv Evid 13:47-50

Ridding LE, Redhead JW, Pywel RF (2015) Fate of semi-natural grassland in England between 1960 and 2013: a test of national conservation policy. Glob Ecol Conserv 4:516-525. https://doi. org/10.1016/j.gecco.2015.10.004

Rundlöf M, Persson AS, Smith HG, Bommarco R (2014) Late-season mass-flowering red clover increases bumble bee queen and male densities. Biol Conserv 172:138-145. https://doi.org/10.1016/j. biocon.2014.02.027

Sattler C, Nagel UJ (2010) Factors affecting farmers' acceptance of conservation measures-A case study from north-eastern Germany. Land Use Policy 27:70-77. https://doi.org/10.1016/j.landusepol. 2008.02.002

Schellberg J, Möseler BM, Kühbauch W, Rademacher IF (1999) Long-term effects of fertilizer on soil nutrient concentration, yield, forage quality and floristic composition of a hay meadow in the Eifel mountains, Germany. Grass Forage Sci 54:195-207. https://doi.org/10.1046/j.1365-2494.1999.00166.x

Scheper J, Bommarco R, Holzschuh A, Potts SG, Riedinger V, Roberts SPM, Rundlöf M, Smith HG, Steffan-Dewenter I, Wickens JB, Wickens VJ, Kleijn D (2015) Local and landscapelevel floral resources explain effects of wildflower strips on wild bees across four European countries. J Appl Ecol 52:1165-1175. https://doi.org/10.1111/1365-2664.12479

Schmidt MH, Rocker S, Hanafi J, Gigon A (2008) Rotational fallows as overwintering habitat for grassland arthropods: the case of spiders in fen meadows. Biodivers Conserv 17:3003-3012. https://doi.org/10.1007/s10531-008-9412-6

Shenk JS, Westerhaus MO (1991) Population definition, sample selection, and calibration procedures for near infrared reflectance spectroscopy. Crop Sci 31:469. https://doi.org/10.2135/ cropsci1991.0011183X003100020049x

Smith H, Feber RE, Morecroft MD, Taylor ME, Macdonald DW (2010) Short-term successional change does not predict long-term conservation value of managed arable field margins. Biol Conserv 143:813-822. https://doi.org/10.1016/j.biocon.2009.12.025

Staab K, Yannelli FAA, Lang M, Kollmann J (2015) Bioengineering effectiveness of seed mixtures for road verges: Functional com- position as a predictor of grassland diversity and invasion resistance. Ecol Eng 84:104-112. https://doi.org/10.1016/j.ecoleng. 2015.07.016

Stilma ESC, Smit AB, Geerling-Eiff AB, Struik PC, Vosman B, Korevaar H (2009) Perception of biodiversity in arable production systems in the Netherlands. NJAS - Wagening J Life Sci 56:391-404. https://doi.org/10.1016/S1573-5214(09)80006-7

Tälle M, Deák B, Poschlod P, Valkó O, Westerberg L, Milberg P (2016) Grazing vs. mowing: a meta-analysis of biodiversity benefits for grassland management. Agric Ecosyst Environ 222:200-212

Tarmi S, Helenius J, Hyvönen T (2011) The potential of cutting regimes to control problem weeds and enhance species diversity in an arable field margin buffer strip. Weed Res 51:641-649. https://doi.org/10.1111/j.1365-3180.2011.00888.x

Tiley GED (2010) Biological Flora of the British Isles: Cirsium arvense (L.) Scop. J Ecol 98:938-983. https://doi.org/10.1111/j. 1365-2745.2010.01678.x

Uchida K, Ushimaru A (2014) Biodiversity declines due to abandonment and intensification of agricultural lands: patterns and mechanisms. Ecol Monogr 84:637-658. https://doi.org/10.1890/ 13-2170.1

Uyttenbroeck R, Hatt S, Paul A, Boeraeve F, Piqueray J, Francis F, Danthine S, Frédérich M, Dufrêne M, Bodson B, Monty A (2016) Pros and cons of flowers strips for farmers: a review. Biotechnol Agron Soc Environ 20:225-235

Uyttenbroeck R, Piqueray J, Hatt S, Mahy G, Monty A (2017) Increasing plant functional diversity is not the key for supporting pollinators in wildflower strips. Agric Ecosyst Environ 249:144-155. https://doi.org/10.1016/j.agee.2017.08.014

Walker KJ, Stevens PA, Stevens DP, Mountford JO, Manchester SJ, Pywell RF (2004) The restoration and re-creation of species-rich lowland grassland on land formerly managed for intensive agriculture in the UK. Biol Conserv 119:1-18. https://doi.org/10. 1016/j.biocon.2003.10.020

Zanetti S, Hartwig UA, Luscher A, Hebeisen T, Frehner M, Fischer BU, Hendrey GR, Blum H, Nosberger J (1996) Stimulation of Symbiotic N2 Fixation in Trifolium repens L. under Elevated Atmospheric pCO2 in a Grassland Ecosystem. Plant Physiol 112:575-583. https://doi.org/10.1104/pp.112.2.575 